HortSCIENCE 27(5):450-452. 1992.

\title{
In Vitro Propagation of Heliconia psittacorum by Bud Culture
}

\author{
M.J. Nathan, C.J. Goh, and P.P. Kumar \\ Department of Botany, National University of Singapore, Lower Kent \\ Ridge Road, Singapore 0511
}

Additional index words. multiple shoots, rhizome, tissue culture, micropropagation

Abstract. A protocol was developed for in vitro propagation of Heliconia psittacorum L.f. by culture of terminal and axillary buds of rhizomes. Cultures were initiated on modified Murashige and Skoog (MS) medium containing $40 \mu \mathrm{M} \mathrm{BA}, 150 \mathrm{ml}$ coconut water/liter, $30 \mathrm{~g}$ sucrose/liter, and $2 \mathrm{~g}$ Gelrite/liter. Shoot multiplication was achieved on the above medium without coconut water, but supplemented with $10 \mu$ M BA. Shoots were rooted on MS basal medium and successfully acclimated to greenhouse conditions. Chemical names used: $N$ - (phenylmethyl)-1 $\mathrm{H}$ - purin-6-amine (BA).

The genus Heliconia L. is represented by $\approx 150$ species of tropical plants that constitute the family Heliconiaceae (Donselman and Broschat, 1986; Keng, 1978). Generally, members of the Heliconiaceae are vegetatively propagated using rhizomes (Broschat and Donselman, 1983b). The inflorescences are terminal, brightly hued, and can be either erect or pendulous depending on the species, bearing two or more boat-shaped bracts arising from a central axis (Broschat and Donselman, 1983a).

Vegetatively propagated rhizomes of $\mathrm{Hel}$ iconia spp. cannot now be imported into several countries without stringent quarantine controls because of the discovery of strains of Pseudomonas solacearum (Smith) Smith in diseased plants grown from rhizomes of Heliconia spp. directly imported from Hawaii (Akiew et al., 1990).

Tissue culture has been used as a rapid means of vegetative propagation in the ornamental horticulture industry, enabling the production of disease-free propagules that can be readily disseminated (Chu, 1985). Currently, such methods are not available for the propagation of Heliconia spp. Hence, the present study was undertaken to develop

Received for publication 26 June 1991. Accepted for publication 9 Dec. 1991. We thank the management of Jurong Birdpark, Singapore, for providing plant materials and Ian $\mathbf{M}$. Turner for advice on statistical analysis. The cost of publishing this paper was defrayed in part by the payment of page charges. Under postal regulations, this paper therefore must be hereby marked advertisement solely to indicate this fact. procedures for in vitro propagation of $H$. psittacorum from excised axillary and terminal buds. Pretreatments of the explant source and manipulation of the components of the culture medium were carried out to optimize micropropagation.

Preparation of explants. Shoot explants were obtained from developing rhizomes of $H$. psittacorum growing under field conditions (Fig. 1A). Roots and leaf bases of the rhizomes were removed before being washed

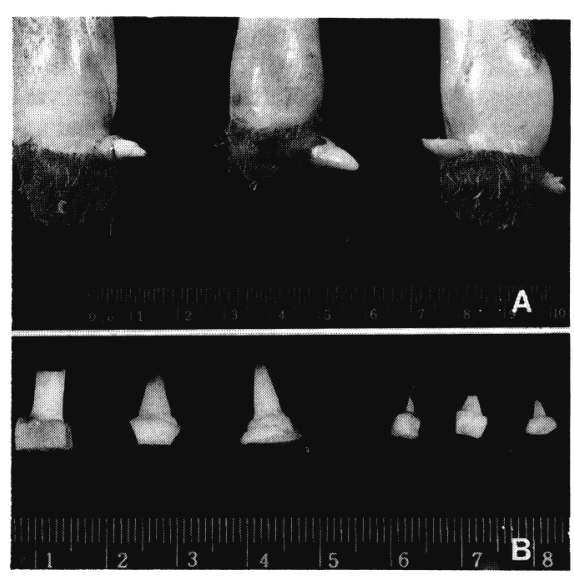

Fig. 1. Rhizomes and buds of Heliconia psittacorum during various stages of preparation of the explants for in vitro culture. Scale divisions in centimeters. (A) Rhizomes with lateral bud development, 7 days after storage in polyethylene bags at room temperature. (B) Three excised buds before sterilization (left), and the appearance of dissected bud explants ready to be inoculated (right). 


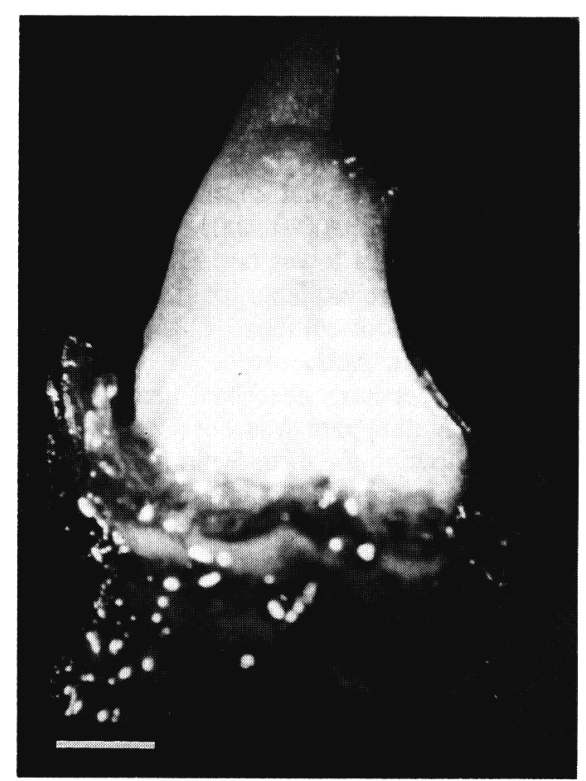

Fig. 2. Bud of Heliconia psittacorum in culture after 6 weeks on medium supplemented with 40 $\mu \mathrm{M}$ BA. Scale bar $=2 \mathrm{~mm}$.

Table 1. Percentage of buds of Heliconia psittacorum responding by growing to a height of 10 to $15 \mathrm{~mm}$ within 6 weeks of culture on establishment medium supplemented with various concentrations of BA and IAA. Calculations were based on the number of buds cultured, and data from two independent experiments, each with eight to 12 buds per treatment, were pooled. Data were subjected to two-way analysis of variance (see Table 2 and text for details).

\begin{tabular}{llllll}
\hline \hline \multirow{2}{*}{$\begin{array}{l}\text { IAA } \\
(\mu \mathrm{M})\end{array}$} & 0 & 10 & 20 & 40 & 80 \\
\cline { 2 - 6 } & \multicolumn{5}{c}{ Buds growing $(\%)$} \\
0 & 0 & 38 & 39 & 53 & 0 \\
1 & 0 & 28 & 23 & 44 & 0 \\
10 & 0 & 29 & 26 & 31 & 0 \\
\hline
\end{tabular}

in tap water. The rhizomes were blotted dry and stored in polyethylene bags for $0,1,3$, 5 , or 7 days at room temperature $(25 \pm 2 \mathrm{C})$. Tissue blocks, $\approx 1 \mathrm{~cm}^{3}$, containing either the apical bud or the prominent axillary bud were excised and washed in running tap water for $15 \mathrm{~min}$, rinsed in $80 \%$ ethanol for $30 \mathrm{sec}$, and immersed for $15 \mathrm{~min}$ in a $0.8 \% \mathrm{NaOCl}$ solution with continual agitation. Following surface sterilization, buds were rinsed twice with sterile distilled water for 5 min each time. The outer tissues of each bud were further trimmed to $\approx 3 \mathrm{~mm}^{3}$ and used as explants (Fig. 1B). Before culture, explants were again surface-sterilized with a $0.4 \% \mathrm{NaOCl}$ solution for $10 \mathrm{~min}$ and rinsed with sterile distilled water as above.

Culture conditions. The culture medium used was Murashige and Skoog (1962) inorganic salts supplemented with the following (in mg.liter ${ }^{-1}$ ): thiamine- $\mathrm{HCl}, 0.5$; myoinositol, 100; sodium hydrogen phosphate, 170; adenine sulphate, 80; and sucrose, 30,000. Gelrite, 2 g.liter ${ }^{-1}$ (Merck \& Co., Rahway, N.J.), was used as the solidifying agent. The combination noted was desig-

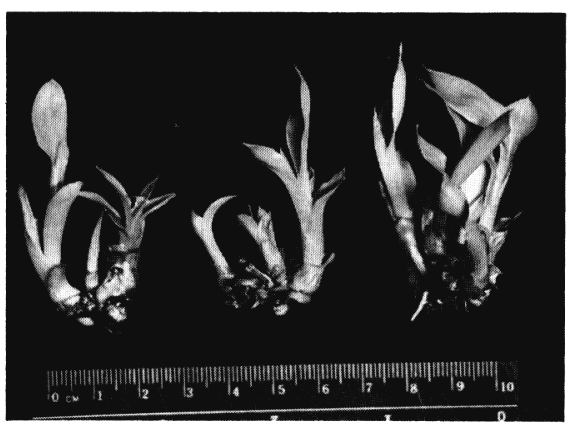

Fig. 3. Multiple shoot development from shoot buds of Heliconia psittacorum cultured for 6 weeks on medium with $10 \mu \mathrm{M}$ BA. Explants were initially cultured for 3 months on medium with $40 \mu \mathrm{M}$ BA, followed by 2 months on medium with $20 \mu \mathrm{M}$ BA before transfer to the present medium. Scale divisions in centimeters.

nated as the basal medium. Coconut water (150 ml-liter $\left.{ }^{-1}\right), \mathrm{BA}$, and $1 \mathrm{H}$ - indole-3-acetic acid (IAA) were incorporated into this medium as required. The coconut water (liquid endosperm) used in these experiments was obtained from 6- to 7-month-old green coconuts (Cocos nucifera L. 'Malayan Tall'). It was deproteinated by boiling, then filtered through one sheet of Whatman 4 filter paper (Whatman Intl., Maidstone, England) and stored at -20C. The $\mathrm{pH}$ of the media was adjusted to $5.7 \pm 0.1$, and the media were autoclaved for $20 \mathrm{~min}$ at $121 \mathrm{C}$.

Cultures were established in $150-\mathrm{ml}$ borosilicate test tubes with $15 \mathrm{ml}$ of medium and one bud per tube. Multiplication and rooting of shoots was carried out in Magenta GA-7 containers (Sigma Chemical Co., St Louis) with $60 \mathrm{ml}$ of the appropriate medium and four shoots per container. All cultures were incubated at $26 \pm 1 \mathrm{C}$ with a 16 -h photoperiod provided by cool-white fluorescent lamps. The lamps provided a photosynthetic photon flux of $60 \mu \mathrm{mol} \cdot \mathrm{m}^{-2} \cdot \mathrm{s}^{-1}$ at the level of the explants as measured with a LI-COR LI-185B quantum/radiometer/photometer (LICOR, Lincoln, Neb.). Shoots were subcultured at 3-week intervals for the first 2 to 3 months and at 6-week intervals during shoot proliferation.

All studies were conducted with eight to 12 replicates per treatment, with at least two independent experiments of a completely randomized design. Percentage data were subjected to arcsin transformation before oneor two-way analysis of variance (ANOVA) where indicated, using STATGRAPHICS software (Statistical Graphics Corp., Rockville, Md.).

Establishment of buds in culture. Buds were placed on basal medium containing coconut water; BA at $0,10,20,40$, or $80 \mu \mathrm{M}$; and IAA at 0,1 , or $10 \mu \mathrm{M}$ in factorial combination (Table 1). Treatments with BA stimulated swelling of the buds in the first 4 weeks of culture. Color of the buds changed from creamy white to green within 7 to 14 days. In the absence of BA, bud development was arrested. With increasing concentrations of BA from 10 to $40 \mu \mathrm{M}$, the buds enlarged. However, at $80 \mu \mathrm{M} \mathrm{BA}$ the buds remained

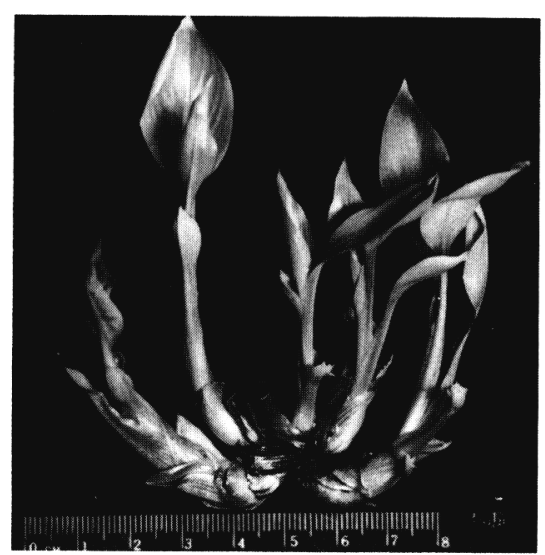

Fig. 4. Uniformly elongated shoots on medium supplemented with $10 \mu \mathrm{M}$ BA before rooting. Scale divisions in centimeters.

Table 2. Two-way analysis of variance of survival and response of buds of Heliconia psittacorum in establishment medium (data from Table 1):

\begin{tabular}{lrcrrr}
\hline \hline & \multicolumn{2}{c}{ Survival } & & \multicolumn{2}{c}{ Response } \\
\cline { 2 - 3 } \cline { 5 - 6 } $\begin{array}{l}\text { Source of } \\
\text { variation }\end{array}$ & df & $\begin{array}{c}\text { Mean } \\
\text { square }\end{array}$ & & df & \multicolumn{1}{c}{$\begin{array}{c}\text { Mean } \\
\text { square }\end{array}$} \\
\hline BA concn & 4 & $0.1037^{\text {NS }}$ & & 4 & $0.6228^{* * *}$ \\
IAA concn & 2 & $0.0236^{\text {NS }}$ & & 2 & $0.0291^{\text {NS }}$ \\
BA $\times$ IAA & 8 & $0.0091^{\text {NS }}$ & & 8 & $0.0201^{\text {Ns }}$ \\
Error & 15 & 0.0364 & & 15 & 0.0237 \\
\hline
\end{tabular}

Ns,***Nonsignificant or significant at $P=0.001$.

green with no enlargement. The majority of buds on medium with $40 \mu \mathrm{M} \mathrm{BA}$ and $0 \mu \mathrm{M}$ IAA continued to enlarge. There was no observable difference in buds on $40 \mu \mathrm{M} \mathrm{BA}$ and varying concentrations of IAA. Two-way ANOVA indicated that at all levels of BA, the concentrations of IAA tested had no significant effect on survival (range $50 \%$ to $84 \%$ ) and enlargement of the buds (Table 2). Also, there was no significant interaction between BA and IAA at the levels tested. The maximum number growing cultures $(53 \%)$ were recorded at $40 \mu \mathrm{M} \mathrm{BA}$ at the end of 6 weeks of incubation (Table 1). This treatment yielded a significantly better response than either 10 or $20 \mu \mathrm{M} \mathrm{BA}\left(\chi 1^{2}=15.56\right.$ and 13.57 , respectively, at $P<0.001)$. Since ANOVA indicated no significant effect of IAA on bud enlargement (response), data within each concentration of BA were pooled before the chi-square test. After 8 weeks of culture, explants from all treatments were transferred to medium containing $40 \mu \mathrm{M} \mathrm{BA}$.

The maximum number of buds suitable for culture was obtained from rhizomes stored for 7 days in polyethylene bags (Table 3 ). No fungal or bacterial infection was observed during storage of the rhizomes, and contamination in vitro was the lowest $(\approx 33 \%)$ in cultures established from these buds as compared to buds from rhizomes stored for less than 1 day (>90\% contamination). Although the cut edges turned brown, the rhizomes remained turgid up to 7 days in storage. Preliminary studies indicated that storage in excess of 9 days under the same conditions 


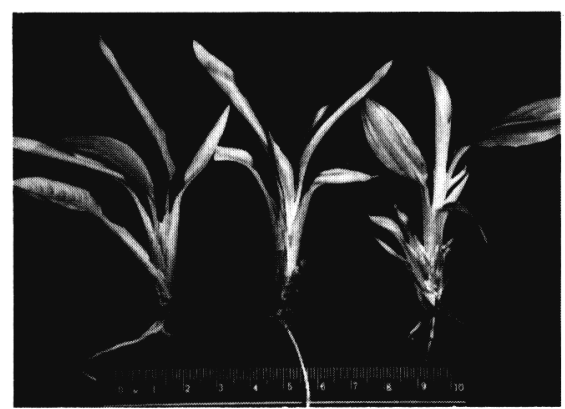

Fig. 5. Root development on elongated shoots of Heliconia psittacorum after 4 weeks of incubation on basal medium. Scale divisions in centimeters.

Table 3. Effect of storage of rhizomes of Heliconia psittacorum at $25 \pm 2 \mathrm{C}$ on the total number of bud explants obtained and the number of uncontaminated and responding buds after 6 weeks of culture on the initiation medium (values are combined means per seven rhizomes). Data were obtained from two independent experiments, each with seven rhizomes per treatment.

\begin{tabular}{lccc}
\hline \hline $\begin{array}{c}\text { Storage } \\
\text { (days) }\end{array}$ & $\begin{array}{c}\text { No. bud } \\
\text { explants } \\
\text { obtained }\end{array}$ & $\begin{array}{c}\text { No. } \\
\text { uncontaminated } \\
\text { buds }\end{array}$ & $\begin{array}{c}\text { No. } \\
\text { buds }\end{array}$ \\
\hline 0 & $22 \mathrm{a}^{\mathrm{z}}$ & $2 \mathrm{a}$ & $2 \mathrm{a}$ \\
1 & $28 \mathrm{ab}$ & $2 \mathrm{a}$ & $2 \mathrm{a}$ \\
3 & $34 \mathrm{bc}$ & $14 \mathrm{~b}$ & $5 \mathrm{a}$ \\
5 & $34 \mathrm{bc}$ & $19 \mathrm{bc}$ & $15 \mathrm{~b}$ \\
7 & $42 \mathrm{c}$ & $28 \mathrm{c}$ & $27 \mathrm{~b}$ \\
\hline
\end{tabular}

${ }^{z}$ Mean separation in columns by the multiple range test of $95 \%$ confidence interval after one-way analysis of variance.

Table 4. Effect of BA concentration on multiple shoot induction, mean shoot length, and the percentage of cultures of Heliconia psittacorum with roots after 6 weeks of incubation. The data are means of two independent experiments, each with six cultures per treatment and four explants per culture.

\begin{tabular}{cccc}
\hline \hline $\begin{array}{c}\text { BA concn } \\
(\mu \mathrm{M})\end{array}$ & $\begin{array}{c}\text { No. shoots/ } \\
\text { explant } \\
\pm \mathrm{SE}\end{array}$ & $\begin{array}{c}\text { Shoot length } \\
(\mathrm{cm}) \\
\pm \mathrm{SE}\end{array}$ & $\begin{array}{c}\text { Cultures } \\
\text { with roots } \\
(\%)\end{array}$ \\
\hline 0.0 & $2.3 \pm 0.6$ & $3.6 \pm 0.3$ & 92.9 \\
5.0 & $2.2 \pm 0.5$ & $3.1 \pm 0.3$ & 0.0 \\
10.0 & $5.0 \pm 0.3$ & $4.8 \pm 1.4$ & 0.0 \\
20.0 & $3.5 \pm 0.7$ & $4.2 \pm 1.0$ & 0.0 \\
40.0 & $2.8 \pm 0.5$ & $2.1 \pm 0.3$ & 0.0 \\
\hline
\end{tabular}

resulted in excessive browning and desiccation of the rhizomes. Storage of rhizomes before explanting also enhanced bud survival. After 6 weeks in culture, $64 \%$ of buds from rhizomes stored for 7 days responded well in the initiation medium containing 40 $\mu \mathrm{MBA}$, in contrast to $<9 \%$ of buds from rhizomes stored for 0 or 1 day. Buds were considered to be responding only when they grew to a height of $\approx 10$ to $15 \mathrm{~mm}$ within 6 weeks of culture (Fig. 2). George and Sherrington (1984) reported that changes in am-

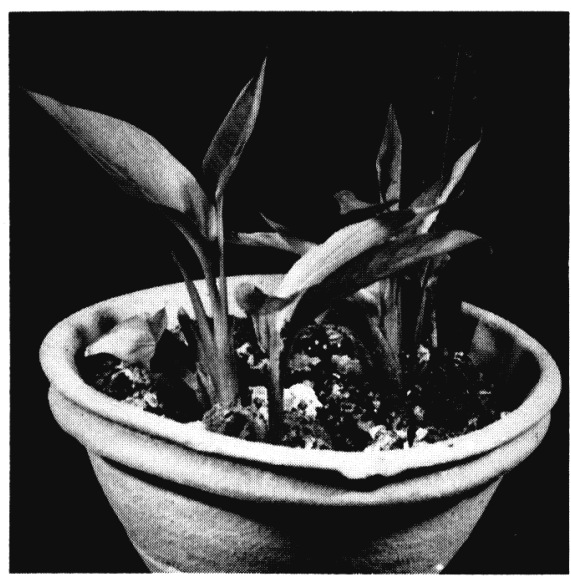

Fig. 6. Acclimated plantlets of Heliconia psittacorum $\approx 1$ month after transplant. Scale divisions in centimeters.

bient conditions, such as light, temperature, and availability of water, will result in plants having altered levels of stored carbohydrates, proteins, and growth substances within their tissues. Similar changes that might have occurred during varying durations of storage of these rhizomes could have affected the response of the excised buds in culture.

Multiplication and in vitro rooting of shoots. If the buds were maintained on the establishment medium (40 $\mu \mathrm{M} \mathrm{BA})$ for longer than 3 to 4 months, apart from an increase in size, there was no significant increase in shoot multiplication over BA-free medium. To bring about production of multiple shoots, BA was tested at varying concentrations $(0$, $5,10,20$, or $40 \mu \mathrm{M}$ ) in medium without coconut water. The maximum rate of shoot proliferation was observed on medium with $10 \mu \mathrm{M}$ BA within 6 weeks of transfer (Table 4, Figs. 3 and 4). Two types of shoots were initiated from intact buds: single shoots from the main axis and three to five shoots presumably from axillary buds at the base of the explants. When apical dominance was removed by halving the buds longitudinally, two to three shoots developed from the leaf axils in each half (Fig. 3). With increasing levels of BA (20 and $40 \mu \mathrm{M})$, the shoots produced were smaller and more compact.

Shoots did not proliferate when BA was omitted from the medium; instead, rooting was observed in $92 \%$ of these shoots (Fig. 5). After root development, which occurred during 6 weeks, plantlets were transplanted to pots containing a medium of 1 vermiculite $: 1$ peat $(\mathrm{v} / \mathrm{v})$ and placed under high humidity and low light intensity for acclimatization. After 4 weeks, plants were transferred to greenhouse conditions, with $90 \%$ survival (Fig. 6)

Results of our micropropagation experiments with heliconia are comparable to previous reports on initiation and proliferation of shoot cultures of bananas [Musa xpar- adisiaca L. 'Saba' and 'Pelipita' and Musa spp. (Jarret et al., 1985; Krikorian and Cronauer, 1986; Wong, 1986)]. BA has been used consistently in these experiments with bananas, particularly at 10 to $20 \mu \mathrm{M}$. In $H$. psittacorum, bud initiation requires a higher concentration of BA $(40 \mu \mathrm{M})$, but shoot proliferation needs a lower one $(10 \mu \mathrm{M})$. Further, halving the explants longitudinally, as practiced in shoot cultures of banana, is not essential for $H$. psittacorum.

Using procedures described here, a fivefold propagation rate was obtained every 6 weeks following the 4- to 5-month initiation phase. These procedures have been suceessfully applied to four cultivars of $H$. psittacorum ('Golden Torch', 'Orange', 'Andromeda', and 'Sassy Kaleidoscope'). A pendulous species, $H$. rostrata Ruiz \& Pavón, has also been successfully cloned.

\section{Literature Cited}

Akiew, S., K. Hyde, L. Diatloff, and R. Peterson. 1999. Bacterial wilt of heliconia plants from Oahu. Hawaii. Austral. Ctr. Intl. Agr. Res. Bacterial Wilt Nwsl. 6. p. 5.

Broschat, T.K. and H.M. Donselman. 1983a. Heliconias: A promising new cut flower crop. HortScience 18:2.

Broschat, T.K. and H.M. Donselman. 1983b. Production and postharvest culture of Heliconia psittacorum flowers in south Florida. Proc. Fla. State Hort. Soc. 96:272-273.

Chu, I.Y.E. 1985. The application of tissue culture to plant improvement and propagation in the ornamental horticulture industry, p. 15-35. In: R.H. Zimmerman, R.J. Griesbach, F.A. Hammerschlag, and R.H. Lawson (eds.). Tissue culture as a plant production system for horticultural crops. Martinus Nijhoff Publishers, Dordrecht, The Netherlands.

Donselman, H. and T.K. Broschat. 1986. Production of Heliconia psittacorum for cut flowera in south Florida. Fort Lauderdale Res. Educ. Ctr. Ornamentals Res. Rpt. 86-1.

George, E.F. and P.D. Sherrington. 1984. Plant propagation by tissue culture: Handbook and directory of commercial laboratories. Exegetics, Reading, U.K.

Jarret, R.L., W. Rodriguez, and R. Fernandez. 1985. Evaluation, tissue culture propagation and dissemination of 'Saba' and 'Pelipita' plantains in Costa Rica. Scientia Hort. 25:137-147.

Keng, H. 1978. Orders and families of Malayan seed plants. Singapore Univ. Press, Singapore.

Krikorian, A.D. and S.S. Cronauer. 1986. Banana. p. 327-347. In: P.V. Ammirato, D.A. Evans, W.R. Sharp, and Y. Yamada (eds.). Handbook of plant cell culture. vol. 3. Macmillan, New York.

Murashige, T. and F. Skoog. 1962. A revised medium for rapid growth and bioassaya with tobacco tissue cultures. Physiol. Plant. 15:473497.

Wong W.C. 1986. In vitro propagation of banana (Musa spp.): Initiation, proliferation and development of shoot-tip cultures on defined media. Plant Cell, Tissue Organ Culture 6:159166 